\title{
Evidences of Rapid Environmental Evolution of Obhur Creek, Eastern Coast of Red Sea: Physical and Chemical Properties
}

\author{
${ }^{1,2}$ Amr A. El-Maradny, ${ }^{1,2}$ Yasser A. Shaban, ${ }^{1}$ Radwan K. al-Farawati, ${ }^{1}$ Mohamed Orif, \\ and ${ }^{1}$ Mohamed Ghandourah
}

${ }^{1}$ Faculty of Marine Sciences, King Abdulaziz University, P.O. Box 80207, Jeddah 21589, Saudi Arabia, and ${ }^{2}$ National Institute of Oceanography and Fisheries, Qait Bay, Alexandria, Egypt amaradny@hotmail.com

\begin{abstract}
Fifteen surface water samples were collected from Obhur Creek to assess the water quality and environmental conditions. Hydrographical parameters indicated gradual increase in salinity from mouth to the head of Creek, whereas dissolved oxygen showed supersaturation in most stations. Average concentration of nutrient ions was found to be $0.79,0.03,0.51,1.04,0.103$ $\mu \mathrm{mol} / \mathrm{l}$ for ammonium, nitrite, nitrate, silicate, and phosphate ions, respectively. These data showed relative increase compared to the previous intensive study for Obhur Creek during 2008. The concentrations of organic nitrogen and organic phosphorus were found to be 6.79 and 1.72 $\mu \mathrm{mol} / 1$, respectively, which are higher than coastal values. The ratio of total inorganic nitrogen/phosphate for the Creek was calculated giving average value of 42, indicating phosphorus limitation for phytoplankton production. The data of nutrients suggests relative change in the trophic level of Obhur Creek from oligotrophic to mesotrophic, which consider as starting point for dramatic changes in this coastal area.
\end{abstract}

Keywords: Obhur Creek, Red Sea, nutrients, mesotrophic.

\section{Introduction}

Trophic level of Red Sea is classified as oligotrophic due to the low concentrations of bio-limiting elements, leading to low productivity of seawater (Edwards and Head 1987). However, along the coastal waters of central part of Red Sea, the environmental conditions enhance the primary productivity most of the year (El-Sayed, 2002). Moreover, in the restricted water circulation areas like Obhur Creek, anthropogenic inputs of nutrients probably increase eutrophication events in marine environments. Eutrophication is believed to cause serious environmental problems, particularly in semi-closed areas (Vilicic, 1989; Puigserver et al., 2002). A series of changes in the abiotic and biotic parameters occur as a result of eutrophication. In the marine environments, several abiotic changes are expected due to eutrophication such as: dissolved oxygen supersaturation and under saturation during phytoplankton blooming, accumulation of organic matter in the seafloor, and deficiency of nutrients in the surface water. On the other hand, biotic changes showed accelerated growth of algae and higher forms of plant life (Vilicic, 1989; Puigserver et al., 2002). Finally, both biotic and abiotic changes lead to an undesirable disturbance to the balance of organisms and the water quality (El-Sayed et al., 2011).

Obhur Creek is one of the natural Creeks lying along Jeddah coast. Jeddah city is one of the 
most important urban cities on the eastern coast of the Red Sea. The city showed economic expansion represented by large number of factories in different industrial activities, as well as its population expansion gives rise to increasing either treated or untreated sewage disposal to the coastal waters. Moreover, considerable amount of contaminants inter the marine environment to the coastal waters through the desalination plant and seaport. These sources of contaminations showed wide variety of pollutants, where nutrients consider as important class of these pollutants.

Several monitoring and environmental surveys of Jeddah coast partially including Obhur Creek have been concerned nutrients (El-Rayis et al., 1982; El-Rayis and Eid 1997; Touliabah et al., 2010; Ba-Akdah et al., 2008; Turki, and Mudarris 2008; Al-Farawati 2010; Gazzaz, 2007). Most of these studies focused mainly on the heavy polluted areas along Jeddah coast like Al-Shabab and Al-Arbaeeen lagoons. Although Obhur Creek is one of the major attraction for tourists in Jeddah, monitoring of its water quality and environmental status is still limited (Al-Farawati et al., 2008). During the last few years, a number of new restaurants, marines, private and public chalets were constructed in Obhur Creek, which expected to change the environmental conditions of the Creek due to human activities stress. This study is considered as an effort to monitor the changes in the water quality of Obhur Creek. The study aims to intensively detecting the hydrographical parameters (temperature $(\mathrm{T})$, hydrogen ion concentration $(\mathrm{pH})$, salinity (S\%), and dissolved oxygen (DO)), concentration of nutrient salts (ammonium $\left(\mathrm{NH}_{4}^{+}\right)$, nitrite $\left(\mathrm{NO}_{2}{ }^{-}\right.$ ) , nitrate $\left(\mathrm{NO}_{3}{ }^{-}\right)$, phosphate $\left(\mathrm{PO}_{4}^{-3}\right)$, and silicate $\left.\left(\mathrm{SiO}_{4}^{-}\right)\right)$, total dissolved nitrogen (TDN), organic nitrogen (ON), total dissolved phosphorous (TDP), and organic phosphorus
(OP) as well as chlorophyll a (Chl. a). The data will be used to identify the trophic level of Obhur Creek.

\section{Study Area}

Obhur Creek is located at a distance of $35 \mathrm{~km}$ north of Jeddah city on the eastern coast of the Red Sea. It has a length of $11 \mathrm{Km}$ and the width varies between 300 to $500 \mathrm{~m}$. Water depth at Obhur Creek mouth is around $50 \mathrm{~m}$, and decreases to reach $3 \mathrm{~m}$ at the end of the Creek. Along the southern side of Obhur Creek, a number of restaurants and marinas were constructed. The northern side of Obhur Creek is fully occupied, mainly with private and public chalets and occasionally with marinas. An extensive use for Obhur Creek by public through activities like yachting, sea skating and other maritime sports are pronounced in last few years.

Fifteen sampling stations lies between $21^{\circ} 45^{\prime}$ 46.3" $\mathrm{N}$ and $21^{\circ} 42^{\prime} .23 .1^{\prime \prime} \mathrm{N}$ were selected to represent uniform geographic coverage of the Creek. Particular attention was given to the dense human activities areas inside the Creek (Fig. 1).

\section{Material and Methods}

Sampling was carried out by the beginning of April 2014, using a small $8 \mathrm{~m}$ outboard. 5L Niskin bottle was used to collect subsurface water $(30 \mathrm{~cm}$ under the surface) samples. Samples were transferred in pre-cleaned $1 \mathrm{~L}$ low-densitypolyethylene bottles for nutrients analysis and kept at $4{ }^{\circ} \mathrm{C}$ for retard biological actions; directly after return to the laboratory, GFC membrane filters were used for sample filtration. Filtered samples were stored at $4{ }^{\circ} \mathrm{C}$ for delayed analysis. Nutrients were analyzed according to colorimetric methods as described by Grasshoff et al. (1999). Total nitrogen and total phosphorous were analyzed simultaneously according to Valderrama method (1981). Three blanks and five duplicated samples were analyzed throughout 
the set of fifteen samples. Pre-calibrated Hydrolab model Multi Parameter Water Quality Sonde 6600V2 with 650 MDS was used for in situ recording of $\mathrm{DO}, \mathrm{pH}, \mathrm{S} \%$, T, and Chl.a parameters.

\section{Results and Discussion}

\section{I- Hydrographical Parameters}

Table 1 and Fig. 2 represent the measured physical parameters: $\mathrm{DO}, \mathrm{pH}, \mathrm{S} \% \mathrm{o}, \mathrm{T}$, and Chl$\mathrm{a}$ in addition to calculated values for the oxygen saturation percentage (OS \%) for surface water in the study area.

Average value for salinity was found to be $39.18 \%$, in agreement with the surface water salinity of Red Sea (39.20\%) (Edwards and Head 1987). Minimum value (39 \%) of salinity was found at the Creek mouth as the nearest station to the open sea (station 1), while the maximum value $(39.51 \%$ ) was recorded at the head of the Creek (station 15).

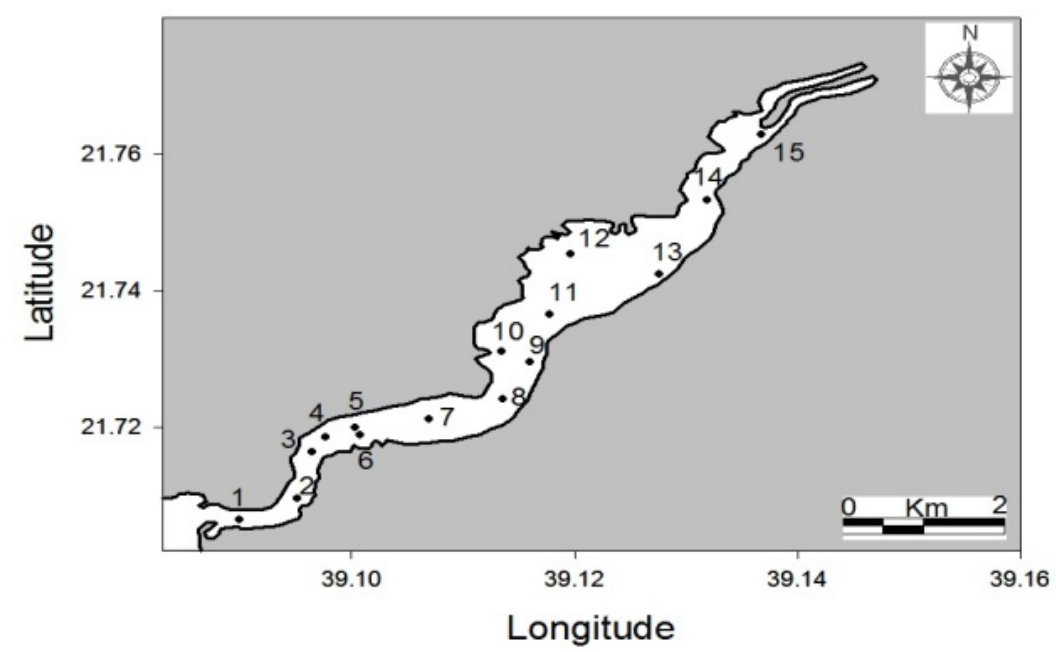

Fig. 1. Map showing the sampling locations in Obhur Creek.

Table 1. Physical parameters: DO, OS \%, pH, salinity, T and Chl. a in Obhur Creek.

\begin{tabular}{|c|c|c|c|c|c|c|}
\hline Station no. & DO $\mathbf{~ g / / ~}$ & OS \%* & $\mathbf{p H}$ & $\mathbf{S \%}$ & $\mathbf{T}^{\circ} \mathbf{C}$ & Chl. a $\boldsymbol{\mu g} / \mathbf{l}$ \\
\hline $\mathbf{1}$ & 6.71 & 105.83 & 8.24 & 39.0 & 26 & 0.5 \\
\hline $\mathbf{2}$ & 6.64 & 104.37 & 8.25 & 39.08 & 26.43 & 0.1 \\
\hline $\mathbf{3}$ & 6.62 & 104.41 & 8.23 & 39.11 & 26.53 & 0.1 \\
\hline $\mathbf{4}$ & 6.65 & 104.89 & 8.24 & 39.12 & 26.61 & 0.1 \\
\hline $\mathbf{5}$ & 6.60 & 104.10 & 8.25 & 39.1 & 26.57 & 0.1 \\
\hline $\mathbf{6}$ & 6.50 & 102.52 & 8.23 & 38.98 & 26.66 & 0.1 \\
\hline $\mathbf{7}$ & 6.57 & 103.63 & 8.25 & 39.11 & 26.66 & 0 \\
\hline $\mathbf{8}$ & 6.64 & 104.73 & 8.24 & 39.12 & 26.43 & 0.2 \\
\hline $\mathbf{9}$ & 6.69 & 105.52 & 8.21 & 39.19 & 26.53 & 0.3 \\
\hline $\mathbf{1 0}$ & 6.52 & 102.84 & 8.22 & 39.20 & 26.61 & 0.5 \\
\hline $\mathbf{1 1}$ & 6.61 & 104.25 & 8.22 & 39.23 & 26.57 & 0.1 \\
\hline $\mathbf{1 2}$ & 6.35 & 100.15 & 8.19 & 39.21 & 26.39 & 0.5 \\
\hline $\mathbf{1 3}$ & 6.4 & 100.94 & 8.22 & 39.33 & 26.8 & 0.8 \\
\hline $\mathbf{1 4}$ & 6.29 & 99.21 & 8.22 & 39.46 & 26.92 & 0.2 \\
\hline $\mathbf{1 5}$ & 6.2 & 97.79 & 8.22 & 39.51 & 26.7 & 0.2 \\
\hline Average & $\mathbf{6 . 5 3}$ & $\mathbf{1 0 3 . 0 1}$ & $\mathbf{8 . 2 3}$ & $\mathbf{3 9 . 1 8}$ & $\mathbf{2 6 . 5 6}$ & $\mathbf{0 . 2 5}$ \\
\hline S.D. & $\mathbf{0 . 1 5 4}$ & $\mathbf{2 . 2 4}$ & $\mathbf{0 . 0 1 6 8}$ & $\mathbf{0 . 1 5 1}$ & $\mathbf{0 . 2 0 8}$ & $\mathbf{0 . 2 2}$ \\
\hline
\end{tabular}

${ }^{*}$ Calculated value based on the theoretical dissolved oxygen (at $26.56{ }^{\circ} \mathrm{C}, 1$ atmosphere, and salinity $39.18 \%$ ) $=6.34 \mathrm{mg} / 1$ 

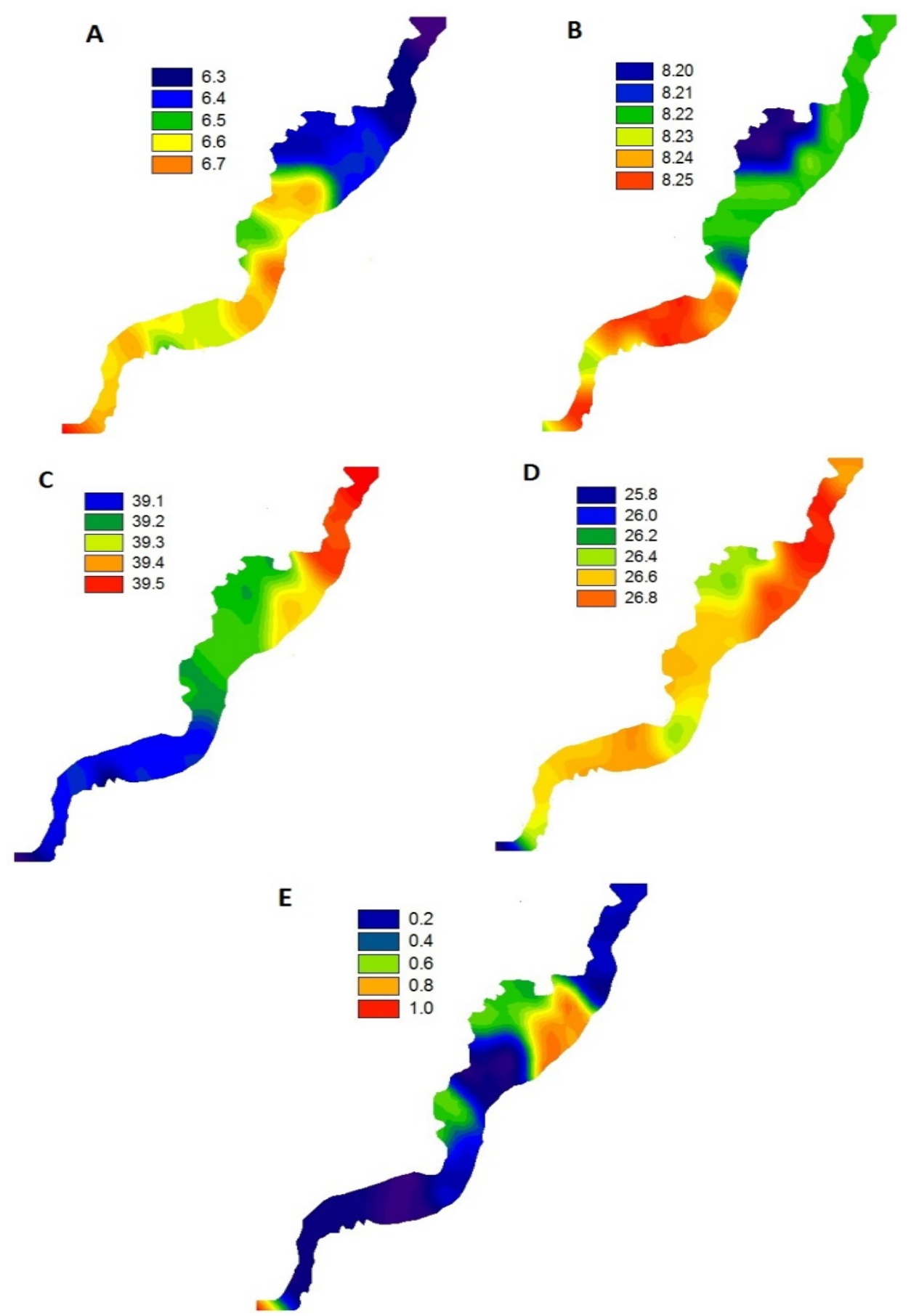

Fig. 2. The distribution of the measured hydrochemical parameters in Obhur Creek. A: DO; B: pH; C: S\%; D: T; E: Chl. a. 
It is clearly that, a graduate increase in the salinity from the mouth to the head in parallel with decreasing the water depth indicating the impact of evaporation. The only exception of the gradual increase in the salinity was recorded at station $6(38.98 \%)$ which is mainly affected by the wastewater from local sources (Fig. 2 C).

The average temperature value recorded in Obhur Creek was $26.56{ }^{\circ} \mathrm{C}$. The changes in the temperature throughout the Creek reflect the geographical changes in the depth at most stations in a similar way as for salinity (Fig. 2 D). The water temperature in the Creek varies from $23.45^{\circ} \mathrm{C}$ in winter to $31.62^{\circ} \mathrm{C}$ in summer and generally increases towards its head (Ahmed and Sultan, 1993).

Average value for $\mathrm{pH}$ was 8.23 that consistent with the values detected during 2008 ranged between 8.27 and 8.15 (Al-Farawati et al., 2008). Lowest $\mathrm{pH}$ values were recorded at station 12 near to the head of the Creek (Fig. 2 B) that may be attributed to the production of $\mathrm{CO}_{2}$ during the remineralization of organic matter. Moreover, the increase of salinity could also contribute to reduction of $\mathrm{pH}$ values; clearly appears in the inverse correlation between the two parameters (Fig. $3)$.

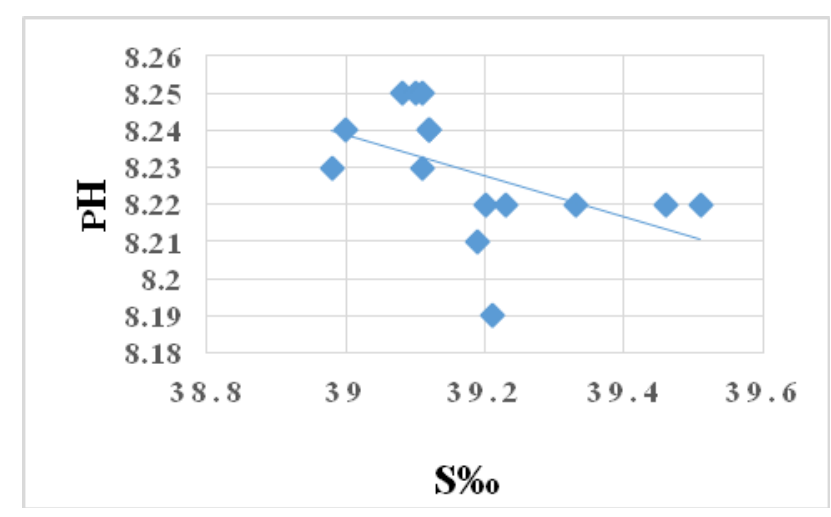

Fig. 3. Correlation between S\%o and $\mathrm{pH}$ values in Obhur Creek.
Several factors control DO concentration in seawater. Physically, the main source was represented by the exchange of oxygen at airsea interface with respect to the other parameters like temperature and salinity. Another important source of oxygen in the surface water is photosynthesis process that usually brings the oxygen concentration to supersaturation levels depending on the biomass intensity and degree of sun light penetration.

On the other hand, oxygen was consumed through respiration process and chemically through aerobic oxidation of organic matter. In the present study, average value of DO was $6.53 \mathrm{mg} / 1(\mathrm{OS} \%=103.01)$, which is relatively higher than the values recorded during 2008; ranged between 6.04 and $6.24 \mathrm{mg} / 1(\mathrm{OS} \%=$ $96 \%)$. The decrease in water temperatures in the two studies $\left(28.09{ }^{\circ} \mathrm{C}\right.$ in the 2008 study and $26.56 \mathrm{C}$ in this study) (Al-Farawati et al., 2008) can partially explain such increase in DO. Highest value for DO $(6.71 \mathrm{mg} / \mathrm{l}$ and $105.83 \%$ ) was recorded at station 1 close to open sea end with relatively high Chl. a concentration $(0.5 \mathrm{mg} / \mathrm{l})$ (Fig. $2 \mathrm{~A}$ and $\mathrm{E})$. Gradual decrease in the DO clearly appear toward the head of the Creek. An exception for this trend was found at station $6(6.50 \mathrm{mg} / \mathrm{l})$ that showed relatively sudden drop in DO probably due to the wastewater from local sources, nevertheless, the average value for OS\% of the water stills supersaturated $(102.52 \%)$. Only stations 14 and 15 near the head of the Creek were recorded as unsaturation (99.21 \% and $97.79 \%$, respectively) (Fig. 2 A). These values can be attributed to the relative high values of salinity and temperature at these two stations, where an inversely proportional between the solubility of oxygen with both salinity $\left(\mathrm{r}^{2}=\right.$ $0.638)$ and temperature $\left(r^{2}=-0.333\right)$ clearly appeared (Fig. 4 and 5). 
Moreover, in such shallow calm water with low circulation, the organic matter is expected to increase leading to further consumption of oxygen during oxidation process especially with low concentration of Chl. a. OS\% is usually used as a tracer for the eutrophication phenomena. It is worth to mention that, OS \% in the surface water in the Obhur Creek changed from unsaturation (96\%) to supersaturation $(103 \%)$ within 6 years. The previous study concluded that, DO only physically controlled and eutrophication due human activities is limited (Al-Farawati et al., 2008), however, the discussion for the chemical parameters in this study will clarify such important change.

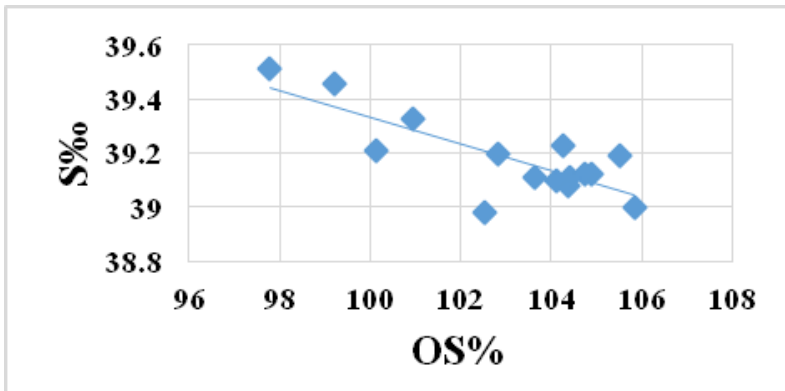

Fig. 4. Correlation between OS\% and S\%o in Obhur Creek.

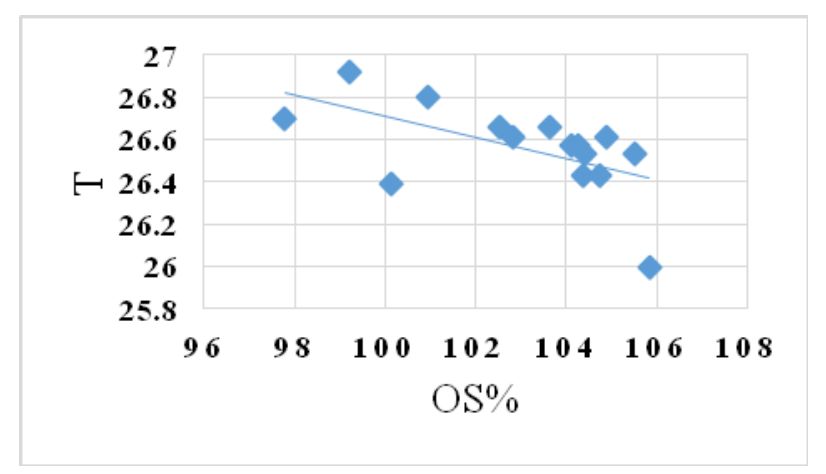

Fig. 5. Correlation between OS\% and T in Obhur Creek.

\section{II- Chemical Parameters}

The main biological needs for plankton are nitrogen, phosphorous and silicon that usually present in low concentrations in the surface water. Hence, these elements are called biolimiting elements (Libes, 2009). The ideal nitrogen biolimiting form for phytoplankton is nitrate ion, which is the dominant form of inorganic nitrogen in seawater (Chester, 2003), while nitrite represents the intermediate in the oxidation - reduction reaction between nitrate and ammonium ion and presents in low concentration. In the oligotrophic surface water like Red Sea, phytoplankton utilizes ammonium ion in photosynthesis (Dugdale and Goering 1967) with respect to the $\mathrm{pH}$ value, which control the different proportions of different nitrogen forms. Recycling of organic matter through oxidation process produces nitrate, ammonium, phosphate and silicate ions consequently with consumption of DO.

Table 2, Fig. 6 and 7 represent the different nitrogen and phosphorous species as well as silicate in the surface water in Obhur Creek.

\section{Phosphate Species}

Average value for $\mathrm{PO}_{4}^{-3}$ in the present study was $0.103 \mu \mathrm{mol} / 1$. This value is in good agreement with the open seawater value $(0.05$ $0.10 \mu \mathrm{mol} / \mathrm{l}$ ) (Edward and Head 1987), and with the values recorded for the two seasons trips on the same area during $2008(0.16$ and $0.08 \mu \mathrm{mol} / 1)$ (Al-Farawati et al., 2008). On the other hand, it is slightly higher than the values recoded in Gulf of Aqaba $(0.06 \mu \mathrm{mol} / \mathrm{l})$ and northern Red Sea $(0.08 \mu \mathrm{mol} / \mathrm{l})(\mathrm{Okbah}$ et al. 1999). Highest value of $\mathrm{PO}_{4}^{-3}(0.42 \mu \mathrm{mol}$ /1) was recorded at station 5, which may be affected by wastewater from research fish farm nearby (Fig. 6 A). Except for station 13, lowest $\mathrm{PO}_{4}^{-3}$ values recorded in parallel with relatively high concentrations of Chl. a as in stations 1,10 and 12 . 
Table 2. Concentration ( $\mu \mathrm{mol} / \mathrm{l})$ of phosphorus and nitrogen species as well as silicate in Obhur Creek.

\begin{tabular}{|c|c|c|c|c|c|c|c|c|c|c|c|c|c|c|}
\hline 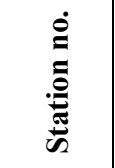 & $\underset{4}{\mathrm{\alpha}_{4}^{+8}}$ & $\hat{0}$ & $\hat{\theta}$ & $\mathrm{OH}_{4}$ & $\stackrel{\dot{0}}{i n}$ & $\begin{array}{l}\mathrm{O}_{3}^{-} \\
\mathrm{Z}^{-}\end{array}$ & $\begin{array}{l}\mathbf{o}_{\mathbf{2}} \\
\mathrm{Z}^{-}\end{array}$ & $\frac{\mathrm{H}_{4}^{+}}{\mathrm{Z}}$ & Z & 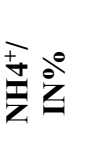 & Z & 目 & 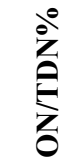 & $\begin{array}{l}\stackrel{0}{+} \\
\stackrel{+}{+} \\
\stackrel{\Delta}{Z}\end{array}$ \\
\hline 1 & 0.06 & 2.11 & 2.18 & 2.75 & 0.98 & 0.32 & 0.008 & 1.01 & 1.35 & 74.81 & 9.46 & 10.82 & 87.43 & 22.5 \\
\hline 2 & 0.15 & 0.8 & 0.96 & 15.62 & 0.85 & 0.29 & 0.05 & 0.71 & 1.06 & 66.98 & 10.2 & 11.27 & 90.50 & 7.07 \\
\hline 3 & 0.11 & 0.78 & 0.89 & 12.36 & 0.47 & 0.19 & 0.05 & 0.48 & 0.72 & 66.66 & 6.9 & 7.63 & 90.43 & 6.54 \\
\hline 4 & 0.12 & 1.09 & 1.21 & 9.91 & 0.43 & 0.23 & 0.004 & 0.3 & 0.54 & 55.55 & 1.49 & 2.04 & 73.04 & 4.50 \\
\hline 5 & 0.42 & 1.82 & 2.24 & 18.75 & 0.63 & 0.3 & 0.02 & 1.09 & 1.43 & 76.22 & 6.29 & 7.72 & 81.48 & 3.40 \\
\hline 6 & 0.11 & 1.04 & 1.15 & 9.56 & 3.18 & 1.83 & 0.02 & 1.06 & 2.92 & 36.30 & 9.44 & 12.36 & 76.37 & 26.54 \\
\hline 7 & 0.15 & 1.51 & 1.66 & 9.04 & 0.83 & 0.36 & 0.03 & 0.9 & 1.3 & 69.23 & 2.83 & 4.13 & 68.52 & 8.67 \\
\hline 8 & 0.09 & 2.15 & 2.24 & 4.02 & 0.98 & 0.15 & 0.04 & 0.84 & 1.04 & 80.77 & 8.27 & 9.31 & 88.82 & 11.56 \\
\hline 9 & 0.01 & 1.33 & 1.34 & 0.74 & 0.92 & 0.09 & 0.06 & 0.14 & 0.3 & 46.66 & 8.24 & 8.54 & 96.48 & 30 \\
\hline 10 & 0.04 & 0.85 & 0.89 & 4.49 & 1.14 & 0.19 & 0.01 & 1.16 & 1.36 & 85.29 & 6.41 & 7.77 & 82.50 & 34 \\
\hline 11 & 0.009 & 1.27 & 1.28 & 0.70 & 0.83 & 1.89 & 0.05 & 1.04 & 2.99 & 34.78 & 4.19 & 7.18 & 58.35 & 332 \\
\hline 12 & 0.02 & 3.38 & 3.4 & 0.58 & 0.94 & 0.33 & 0.03 & 0.34 & 0.71 & 47.88 & 6.91 & 7.63 & 90.56 & 35.5 \\
\hline 13 & 0.19 & 0.89 & 1 & 0.19 & 1.18 & 0.26 & 0.03 & 1.08 & 1.38 & 78.26 & 7.7 & 9.09 & 84.70 & 7.26 \\
\hline 14 & 0.02 & 3.57 & 3.59 & 0.55 & 1.01 & 0.49 & 0.004 & 1.24 & 1.74 & 71.26 & 4.98 & 6.72 & 71.11 & 87 \\
\hline 15 & 0.05 & 3.22 & 3.27 & 1.53 & 1.29 & 0.54 & 0.01 & 0.47 & 1.02 & 46.08 & 8.6 & 9.63 & 89.30 & 20.4 \\
\hline Average & 0.103 & 1.72 & 1.82 & 6.05 & 1.04 & 0.51 & 0.03 & 0.790 & 1.32 & 62.45 & 6.79 & 8.12 & 81.97 & 42.46 \\
\hline S.D. & 0.10 & 0.97 & 0.95 & 6.08 & 0.64 & 0.56 & 0.02 & 0.36 & 0.76 & 16.56 & 2.51 & 2.62 & 10.47 & 82.84 \\
\hline
\end{tabular}

A

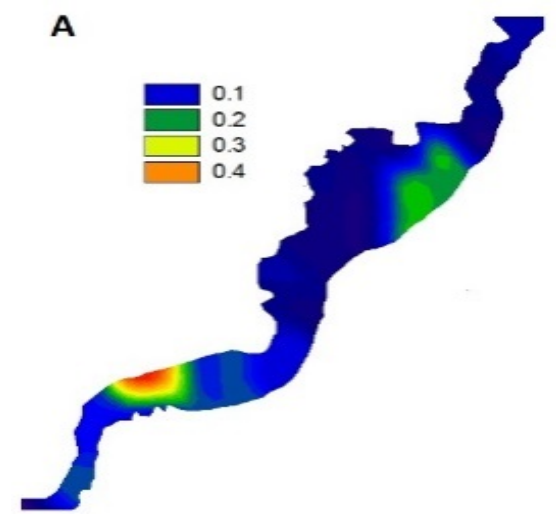

C

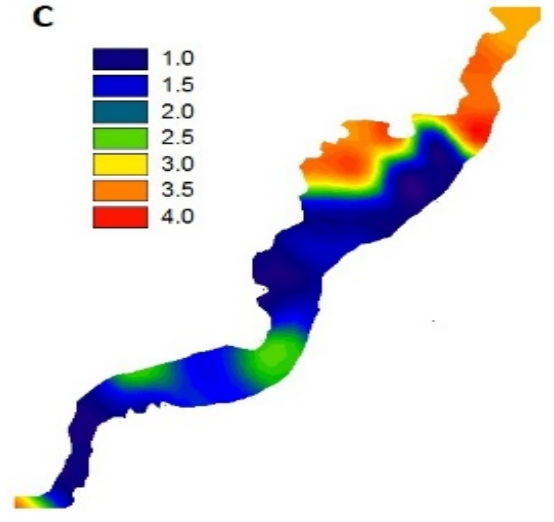

$\mathbf{B}$

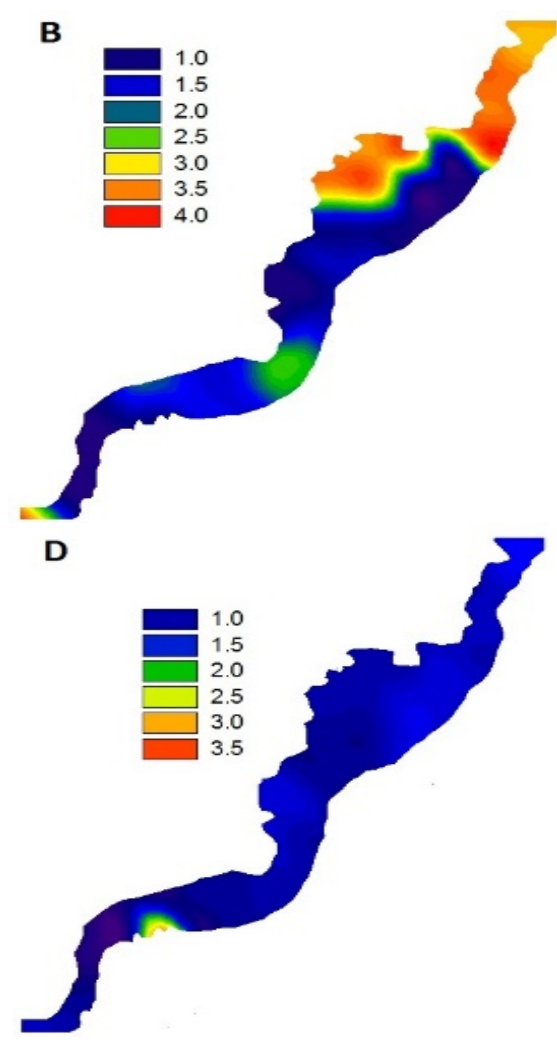


Fig. 6. The distribution of phosphorus species and silicates in Obhur Creek.A: $\mathrm{PO}_{4}^{-3}$; B: OP; C: TDP; D: $\mathrm{SiO}_{4}^{-}$
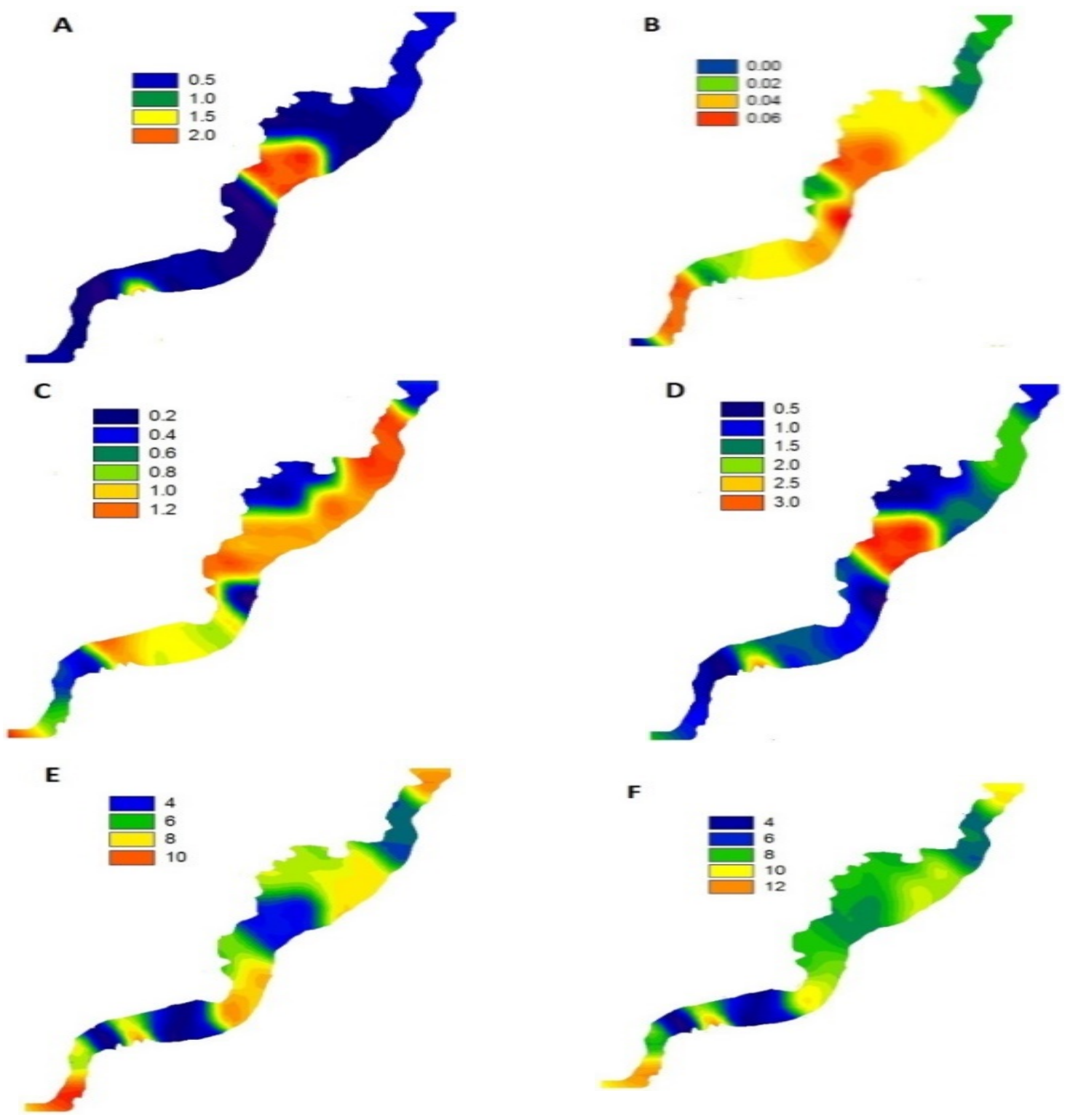

Fig. 7. The distribution of nitrogen species in Obhur Creek. A: $\mathrm{NO}_{3}^{-} ; \mathrm{B}: \mathrm{NO}_{2}^{-} ; \mathrm{C}^{-\mathrm{NH}_{4}^{+}}$; D: IN; E: ON; F: TDN.

Organic phosphorus (OP) is the major reservoir of phosphorus in seawater (Smith et al., 1986), especially in the coastal areas where significant fraction of phosphorus derived from land (Meybeck, 1993).In the present study, OP average concentration was 1.72 $\mu \mathrm{mol} / 1$, which is 17 times higher than the measured inorganic form and represent $94 \%$ of total phosphorous. The range of OP in the surface waters of is between 0.1 and 0.3 $\mu \mathrm{mol} / \mathrm{l}$ (Torre-Valdes et al. 2009), and averaged $1.49 \mu \mathrm{mol} / \mathrm{l}$ in coastal water (Suzumura et al.,1998) and constitutes 35$67 \%$ of total phosphorus (Padayao and McGlone 2000). As expected, highest values for the organic phosphorous were detected at stations 12, 14 and 15 near the head of the Creek (Fig. 6 B).During the rainy season, the 
head of the Creek receives significant amount of nutrients from Wadi Al-Kura northern the Creek, that consumed by phytoplankton (AlFarawati et al., 2008), consequently these plankton deposited as dead organic matter that can acting as a source of phosphate ion through recycling process and transportation across the sediment-water interface (Adriana and Marcos 2005; Martinova, 1993). The limitation of circulation and long flushing time of water in these shallow stations enhance the presence of such high concentration of organic phosphorous; on the same time low concentration of inorganic phosphate ions that bring the average percentage of phosphate/total phosphorus to only $6.05 \%$.

\section{Silicate}

The average value for $\mathrm{SiO}_{4}^{-}$in the study area was $1.04 \mu \mathrm{mol} / 1$. This value is two order of magnitude lower than the values recorded for the same area during $1982(2.0 \mu \mathrm{mol} / \mathrm{l})$ (ElRayis et al.1982), while 10 and 2 times higher than the values recorded in Gulf of Aqaba $(0.55 \mu \mathrm{mol} / 1)$ and northern Red Sea $(0.42$ $\mu \mathrm{mol} / 1)$, respectively (Okbah et al., 1999). The highest value was recorded at station 6 $(3.18 \mu \mathrm{mol} / \mathrm{l})$ (Fig. $6 \mathrm{D})$, which is consistence with the drop in salinity and relative increase for the other nutrients through the wastewater from nearby local sources.

\section{Nitrogen Species}

The concentration of inorganic nitrogen (IN) in seawater are highly variable depending on the location, depth and time of year. In natural seawater the concentration range for ammonium, nitrite and nitrate ions are 0.001$0.57 \mu \mathrm{mol} / \mathrm{l} ; 0.003-0.014 \mu \mathrm{mol} / 1$, and $0.004-$ $2.14 \mu \mathrm{mol} / 1$, respectively (Nollet, and Gelder 2007). In the present study, the average value for nitrate was $0.51 \mu \mathrm{mol} / 1$. This value is slightly lower than its value in the northern Red Sea $(0.62 \mu \mathrm{mol} / \mathrm{l})$, and two order of magnitude are lower than those for the surface

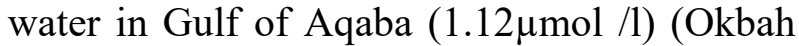
et al., 1999), while it is two order of magnitude higher than the value recorded in the same area during $2008(0.38 \mu \mathrm{mol} / \mathrm{l})$ (AlFarawati et al., 2008). The second highest value for nitrate was $1.83 \mu \mathrm{mol} / 1$ recorded at station 6 (Fig. 7 A), due to the presence of research fish farm nearby that lead to elevation of all nutrients in this station. Average values for nitrite was $0.03 \mu \mathrm{mol} / 1$ is consistence with the values recorded in the Northern Red Sea $(0.04 \mu \mathrm{mol} / 1)$ and 4 times lower than Gulf of Aqaba $(0.13 \mu \mathrm{mol} / 1)$ (Okbah et al., 1999) and 2 times lower than the values recorded during 2008 for the same area $(0.06 \mu \mathrm{mol} / \mathrm{l})$ (AlFarawati et al.,2008). Average value for ammonia was $0.79 \mu \mathrm{mol} / 1$ and ranged between $1.24 \mu \mathrm{mol} / 1$ as highest value recorded at station 14 near the head of the Creek and 0.14 $\mu \mathrm{mol} / \mathrm{l}$ as the smallest value recorded at station 9 (Fig. 7 C). These data are in great consistent with 2008 study especially in April trip (0.78 $\mu \mathrm{mol} / \mathrm{l})$, while represent approximately half of the value for the June trip $(0.44 \mu \mathrm{mol} / \mathrm{l})$ (AlFarawati et al., 2008). Average value of $\mathrm{NH}_{4}{ }^{+} / \mathrm{IN}$ was 62.45 , which is relatively high.

$\mathrm{ON}$ represents the major component of fixed nitrogen in seawater. Although it is biologically inert, but it plays an important role in the oceanic nitrogen cycling, and the benthic fluxes in sedimentary nitrogen cycles (Doval et al., 1997). The concentration of ON in natural seawater ranged between 2 to $5 \mu \mathrm{mol} / 1$ for deep ocean, $1-13 \mu \mathrm{mol} / 1$ in the surface ocean, and 3-19 $\mu \mathrm{mol} / 1$ in the coastal areas (Nollet, and Gelder 2007). ON represents $42-75 \%$ of TDN in coastal areas (Padayao, and McGlone 2000). In the present study, the average concentration of ON was $6.97 \mu \mathrm{mol} / 1$, while it represents $81.97 \%$ of TDN (Fig. 7 F). Surprisingly, highest values for $\mathrm{ON}$ were recorded at stations 1 and 2 near Creek mouth; followed by station 6 near to research fish farm. Stations 13 and 15 near the head of the 
Creek also showed relatively high values of ON (Fig. 7 E), for the same reasons discussed in organic phosphorous section.

Both ON and OP percentages were found higher than the expected values in coastal areas (Padayao, and McGlone 2000; Suzumura et al., 1998). Numerous factors can explain such increase in organic forms of nitrogen and phosphorus including: the low water circulation in such semi-closed area; the wastewater coming from different sources in Obhur Creek that is contaminated by dissolved organic nitrogen and phosphorous compounds; naturally during rainy season from Wadi Alqura area northern the Creek; and finally the probability of restricted eutrophication process. However, the smaller fraction of the organic forms of nitrogen and phosphorous in the open ocean may be much more effective in nutrient recycling/regeneration in the open ocean than in the coastal area (Padayao, and McGlone 2000).

\section{$\mathrm{IN} / \mathrm{PO}_{4}{ }^{-3}$ ratio}

The optimal IN/PO $4^{-3}$ ratio for phytoplankton growth is $16: 1$ that is called the Redfield ratio. The deviations from 16 at low $\mathrm{IN} / \mathrm{PO}_{4}{ }^{-3}$ ratios indicate potential nitrogen limitation, and at high IN/PO ${ }^{-3}$ ratios potential phosphorus limitation of phytoplankton primary production. This might affect the biological state of the ecosystem, in particular the phytoplankton biomass, species composition and eventually food web dynamics (Libes 2009). In the present study, the average value for $\mathrm{IN} / \mathrm{PO}_{4}{ }^{-3}$ ratio was 42.46 indicating potential phosphorus limitation for phytoplankton production, and the highest value recorded at station 11 . It is worth to mention that, by excluding station 11 , the $\mathrm{IN} / \mathrm{PO}_{4}{ }^{-3}$ ratio becomes 16.46 as an optimum ratio for phytoplankton growth. Station 11 showed the highest IN value $(2.99 \mu \mathrm{mol} / \mathrm{l})$ with the lowest $\mathrm{PO}_{4}{ }^{-3}$ value $(0.009 \mu \mathrm{mol} / \mathrm{l})$ that produced one of the lowest Chl. a concentrations $(0.1 \mu \mathrm{g} / \mathrm{l})$ in Obhur Creek. In the previous study during 2008 for the same area, IN/PO $4^{-3}$ ratios were 8.74 and 13.54 during spring and summer seasons, respectively (Al-Farawati et al., 2008), indicating potential nitrogen limitation for phytoplankton production. These data indicate an important change from nitrogen limitation in the previous study (6 years ago $)$ to phosphorus limitation in the present study, which point out to the wastewater quality rich by nitrogen compounds.

\section{Environmental Assessment of Obhur Creek}

Eutrophication degree can be assessed based on the concentration of nutrients in the water body. If the concentrations of $\mathrm{NH}_{4}^{+}$and $\mathrm{NO}_{3}{ }^{-}$ are less than $0.5 \mu \mathrm{mol} / 1$ for each, the system considers as oligotrophic; while the system is a mesotrophic in case the concentration of $\mathrm{NH}_{4}{ }^{+}$ranges between $0.5-2 \mu \mathrm{mol} / 1$ and $\mathrm{NO}_{3}{ }^{-}$ ranges between 0.5-4 $\mu \mathrm{mol} / 1$ (Franco 1983). Phytoplankton biomass expressed as the concentration of Chl. a considers very low if the concentration is less than $1 \mu \mathrm{g} / 1$ (Nixon et al., 1996). In 2008, the average $\mathrm{NH}_{4}{ }^{+}$and $\mathrm{NO}_{3}{ }^{-}$ concentrations were 0.44 and $0.38 \mu \mathrm{mol} / 1$, respectively (Al-Farawati et al., 2008); suggesting oligotrophic nature of the Creek. In the present work, the concentrations of $\mathrm{NH}_{4}^{+}$ and $\mathrm{NO}_{3}{ }^{-}$were 0.79 and $0.51 \mu \mathrm{mol} / 1$ respectively, while Chl. a recorded $0.25 \mu \mathrm{g} / \mathrm{l}$; that mean, the system is classified as mesotrophic. Obviously, there is an increase anthropogenic input of nutrients to Obhur Creek. The rate of nutrients input is expected to accelerate as a result of increasing of population in the next few years. This scenario induces further deterioration of the environment of Obhur Creek. Therefore, extended monitoring program of water quality is important in order to protect the environment of the Creek. 


\section{Conclusion}

At least three stations detected as hot spots in the study area (stations 5, 6, and 11) due to oversupplying of nutrients, while the stations near to the head of the Creek $(12,13,14$, and 15) consider as non-point sources. Considerable amounts of wastewater runoff from hot spot stations lead to several changes in physical and chemical parameters. The changes occur within 6 years for the measured parameters are important and serious. OS\% changed from unsaturation to supersaturation. Average concentration of biolimitimg nutrients $\left(\mathrm{NO}_{3}{ }^{-}, \mathrm{NH}_{4}{ }^{+}\right.$, and $\left.\mathrm{PO}_{4}^{-3}\right)$ were increased. IN/ $\mathrm{PO}_{4}{ }^{-3}$ ratio suggests that phytoplankton growth is limited by phosphorous rather than nitrogen, in contradiction the situation 6 years ago. Finally, trophic level changed from oligotrophic to mesotrophic. These changes indeed are mainly due to the wastewater runoff for at least three stations inside the Creek; such changes must enhance the continuous monitoring of this area; and the overall study presented to stakeholders to take the suitable decision to keep the area clean not only from in-reaching by nutrients but also from all other kinds of expected pollutants.

\section{References}

Adriana, J. and Marcos, G.N. (2005) Temporal and spatial patterns based on sediment and sediment-water interface characteristics along a cascade of reservoirs (Paranapanema River, south-east Brazil), Lake and Reservoir Management, 10: 1-12.

Edwards, A.J. and Head, S.M. (1987) Key Environments: Red Sea. Oxford: Pergamon Press.

Ahmed, F. and Sultan, S.A. (1993) Tidal and sea level changes at Jeddah, Red Sea. Pakistan Journal of Marine Sciences, 2 (2): 1-8.

Al-Farawati, R., Al-Maradni, A. and Niaz, R.G. (2008) Chemical Characteristics (Nutrients, Fecal Sterols and Polyaromatic Hydrocarbons) of the Surface Waters for Sharm Obhur, Jeddah, Eastern Coast of the Red Sea, Journal of King Abdulaziz University, Marine Science, 19: 95-119.
Al-Farawati, R. (2010) Environmental Conditions of the Coastal Waters of Southern Corinche, Jeddah, Eastern Red Sea: Physico-chemical Approach, Australian Journal of Basic and Applied Sciences, 4: 3324-3336.

Ba-Akdah, M. A., Radi, N. I. and Jastania, H. A. (2008) Determination of Some Micro-Nutrient Salt Concentrations of Al-Nawras Lagoon Surface Waters at Jeddah Coast on the Red Sea, Journal of King Abdulaziz University, Marine Science, 19 (1) :29-40.

Chester, R. (2003) Marine Geochemistry. Blackwell Publishing.

Doval, M. D., Fraga, F. and Perez. F. F. (1997) Determination of dissolved organic nitrogen in seawater using Kjeldahl digestion after inorganic nitrogen removal, Oceanologica Acta, 20 (5): 713-720.

Dugdale, R. C. and Goering, J. J. (1967) Uptake of new and generated forms of nitrogen in primary productivity, Limnology and Oceanography 12: 196-203.

El-Rayis, O. A., Abbas, M. M. and Qurashi, A. A. (1982) Distribution of Chemical Pollutants in Jeddah Coastal Waters, Red Sea; I- Phosphate and Silicate, Journal of King Abdulaziz University, Marine Science, 2: 73-80.

El-Rayis, O.A. and Eid, F.M. (1997) Hydrography and water budget of Obhur Creek, Red Sea, Journal of King Abdulaziz University, Marine Science, 8: 29-45.

El-Sayed, M.A., Basaham, A. S. and Gheith, A. M. (2002) Distribution and geochemistry of trace elements in central Red Sea coastal sediments, International Journal of Environmental Studies, 59: 1-31.

El-Sayed, M. A., El-Maradny, A. A., Al-Farawati, R. Kh. and Shaban, Y. A. (2011) Evaluation of the Adequacy of a Rehabilitation Programme, Implemented in Two Red Sea Coastal Lagoons, Using the Hydrological Characteristics of Surface Water, Journal of King Abdulaziz University, Marine Science, 22: 69-108.

Franco, P. (1983) Fatorri influent sulla productivita primaria dell Adriatico Settentrionale Proc. International Conference problems of the Adriatic Sea, Trieste pp 155, A4.

Gazzaz, M. O. (2007) Distribution of phosphorus and nitrogen species and some trace elements in the coastal waters of Eastern Red Sea, M.Sc. Thesis, Faculty of Marine Sciences, King Abdulaziz University.

Grassoff, K., Kremling, K. and Ehrhardt, M. (1999) Methods of Seawater Analysis, Welly-VCH, Weinheim. Newyourk.

Libes, S. (2009) Introduction to marine biogeochemistry, 2nd ed. 909 p. Amsterdam; Boston: Elsevier/Academic Press.

Martinova, M.V. (1993) Nitrogen and phosphorus compounds in bottom sediments: mechanisms of accumulation, transformation and release, Hydrobiologia 252: $1-22$. 
Meybeck, M. (1993) C, N, P and S in rivers: from sources to global inputs. In: Wollast, R., Mackenzie, F. T., Chou, L.; (eds). Interaction of $C, N, P$ and $S$ Biogeochemical Cycles and Global Change, Springer Verlag, 163-193.

Nixon, S. C., Mainstone, C. P., Iverseni, T. M., Kristensen, P., Jeppensen, E., Friberg, N. Papathanassiou, J. A. and Pedersen, F. (1996) The harmonised monitoring and classification of ecological quality of surface waters in the European Union, WRc Report No. CO 4150, Medmenton, UK.

Nollet, L. M. L. and De Gelder, L. S. P. (2007) Technology \& Engineering, Handbook of Water Analysis, Second Edition, CRC Press.

Okbah, M. A., Mahmoud, TH. H. and El-Deek, M. S. (1999) Nutrient Salts Concentrations in the Gulf of Aqaba and Northern Red Sea, Bulletin of the Natural Institute of Oceanography \& Fisheries, Egypt, 25: 103-116.

Padayao, D. O. and McGlone, M. L. S. (2000) Nitrogen and Phosphorus in Coastal Systems: Focus on Dissolved Organic N and P, Science Diliman, 12 (2): 51-58.

Puigserver, M., G., Moyá, R. G. and Martínez-Taberner, A. (2002) Planktonic chlorophyll a and eutrophication in two Mediterranean littoral system (Mallorca Island, Spain), Hydrobiologia, 475/476: 493-503.

Smith, S. V., Kimmerer W. J. and Walsh, T. W. (1986) Vertical flux and biogeochemical turnover regulate nutrient limitation of net organic production in the North
Pacific Gyre, Limnology and Oceanography, 31 (1): 161167.

Suzumura, M., Ishikawa, K. and Ogawa, H. (1998) Characterization of dissolved organic phosphorus in coastal seawater using ultrafiltration and phosphohydrolytic enzymes. Limnology and Oceanography, 43 (7): 15531564.

Torres-Valdes, S., Roussenov, V.M., Sanders, R., Reynolds, S. and Pan, X. (2009) Distribution of dissolved organic nutrients and their effect on export production over the Atlantic Ocean, Global Biogeochemcal, Cycles 23: GB4019.

Touliabah H. E., Abu El-Kheir, W. S., Kuchari, M. G. and Abdulwassi, N. I. H. (2010) Phytoplankton Composition at Jeddah Coast-Red Sea, Saudi Arabia in Relation to some Ecological Factors, Journal of King Abdulaziz University, Marine Science, 22 (1):115-131.

Turki, J. and Mudarris, M. S. (2008) Bacteria and Nutrients as Pollution Indicators in the Al-Nawrus Recreational Lagoon, Jeddah, Journal of King Abdulaziz University, Marine Science, 19 (1): 77-93.

Valderrama, J. C. (1981) The simultaneous analysis of total nitrogen and total phosphorus in natural waters, Marine Chemstry, 10: 109-122.

Vilicic, D. (1989) Phytoplankton population density and volume as indicators of eutrophication in the eastern part of the Adriatic Sea, Hydrobiologia, 174: 117-132.

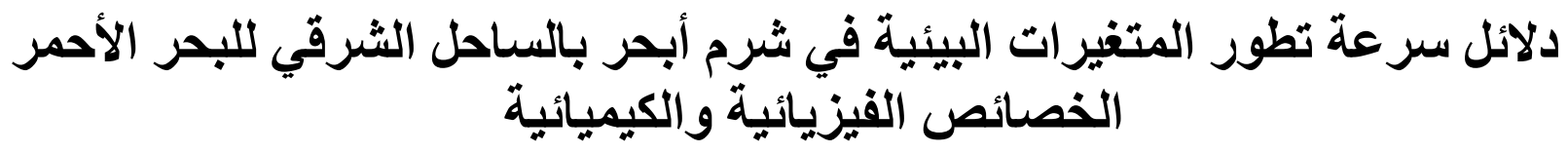


ז، عمرو المرادني"، و ׳، ياسر شعبان، و'رضوان الفرواتي، و 'محمد عريف، و 'محمد غندوره

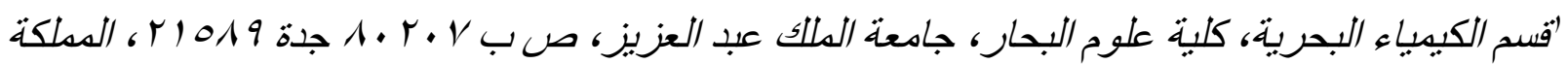

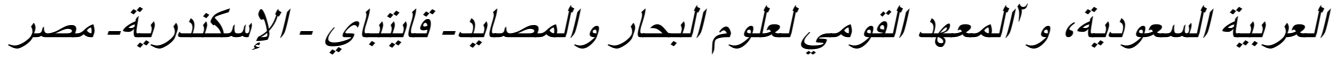

\section{amaradny@hotmail.com*}

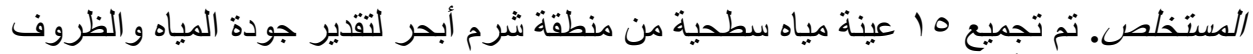

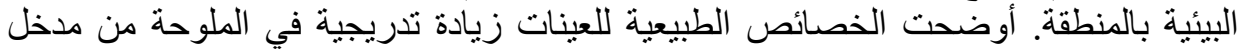

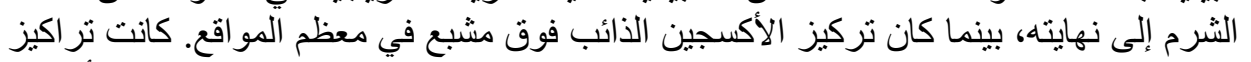

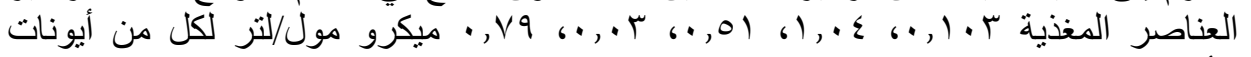

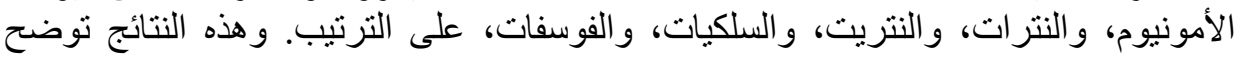

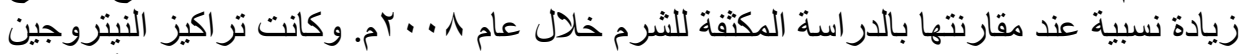

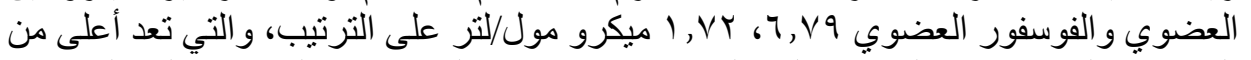

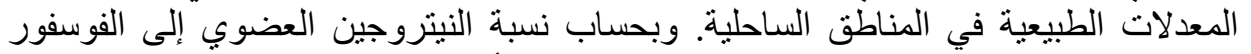

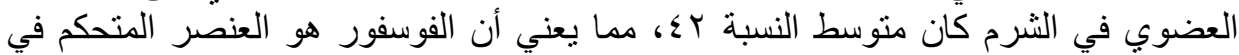

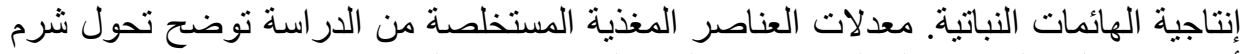

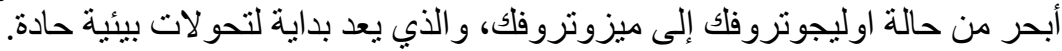

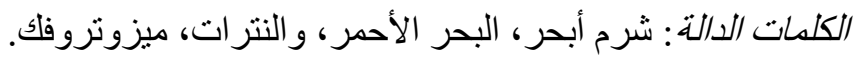

